\title{
26 Research Soure \\ Corporate Ownership and Firm Value: A Gmm-Based Dynamic Panel Data Approach
}

KRISHNA DAYAL PANDEY

Vidyasagar University

TARAK NATH SAHU ( $\nabla$ taraknathsahu1982@gmail.com )

Vidyasagar University https://orcid.org/0000-0001-8017-0728

Research

Keywords: Ownership Composition, Ownership Concentration, Firm Value, Dynamic Panel Data Analysis

Posted Date: September 8th, 2020

DOI: https://doi.org/10.21203/rs.3.rs-68880/v1

License: (c) (i) This work is licensed under a Creative Commons Attribution 4.0 International License. Read Full License 


\section{Abstract}

To establish the relationship between corporate ownership and firm value, static as well as Arellano-Bond dynamic panel model based on Generalised Method of Moments (GMM) are applied on a set of panel data consisting 112 Indian manufacturing firms listed in BSE 200 Index of Bombay Stock Exchange for the period of 2011-18. A significant and positive effect of domestic promoters, foreign promoters and institutional ownership on Tobin's Q is established. Regarding ownership concentration, a U-shaped relationship between ownership of large shareholders and ownership of largest shareholder and firm value is evidenced. At lower level of concentration, the effect on firm value is found to be negative indicating joint effect of 'expropriation of minority shareholders' and 'misaligned interests' of majority owners with the firm. For ownership concentration by large owners and the largest one owner, the effect on firm value is found to be positive after a threshold of 70 and 52 percent respectively. This signifies improved alignment of interests and efficient monitoring of managerial opportunistic behaviour and dismantling of owners-managers agency problem at higher level of concentration. Stricter external regulatory mechanism is suggested as a complimentary force to internal governance to ensure protection of minority shareholders' interest and improved firm valuation.

\section{Introduction}

The empirical relationship between ownership structure and firm performance has attracted great deal of attention from researchers especially of developed countries like United State, United Kingdom and of many Asian and European economies (Berle and Means, 1932; Hill and Snell, 1989; Leech and Leahy, 1991; Franks and Mayer, 1997; Barca and Becht, 2002; Faccio and Lang; 2002; Lemmon and Lins, 2003). Notably, the relationship between ownership structure and firm valuation is largely based on agency theory pioneered by Berle and Means (1932). It postulates that, separated ownership and control arrangement in modern corporation results into unaligned interests of principals and agents leads to inefficient use of corporate resources by the agents resulting into lower firm performance and value. It is commonly agreed among the researchers that there are two possible sources of governance which can mitigate the principle-agent crisis as proposed by the agency theory of Berle and Means (1932), one is the external regulatory forces i.e. the market regulators- cum-legal system and another is the internal disciplinary mechanism (Shleifer \& Vishny, 1986; Coffee, 1991; Heugens et al., 2009). Subsequently, the ownership structure is considered as one of the core internal disciplinary mechanisms and it remains a basis for exercising power and control over the functioning of a corporate entity especially under an 'incomplete agency contract' (Farooque et al., 2007) and an instable or week political, legal and social framework (Roe, 2003; Shleifer and Vishny, 1997). Notably, the perception behind the favourable impact of different forms of ownership on firm value is largely based on the postulation of efficient monitoring hypothesis (Shleifer and Vishny, 1986; Friend and Lang, 1988). According to the hypothesis, the promoters and institutional shareholders, by virtue of their substantial voting rights, expertise and vested interest, are supposed to control the managerial discretion and actively take part in the overall management of affairs of a corporation resulting into reduced type 1 agency problem and thereby increased efficiency, performance and value (Pound, 1988; Chakrabarti, 2005; Kumar and Singh, 2013). In India, the capital market regulator's (SEBI's) Substantial Acquisition of Shares and Takeover Regulations, 1997 and Disclosure and Investment Protection Guidelines, 2000 also recognise promoters, to have significant influence on Indian firms' activities through rigorous monitoring and regulating corporate decision and actions by virtue of their shareholding and management rights. However, regarding institutional ownership, Pound (1988) suggests that the effect of institutional ownership on firm value is conditioned under two more well-accepted hypotheses; conflict-of-interest hypothesis and strategicalignment hypothesis. Both of these hypotheses postulate a negative impact of institutional ownership on the valuation of firm.

Again, ownership concentration is an endemic feature of most of the jointly held Indian corporations since the days of British managing agencies (Balasubramanian, 2010). Not only India, even most of the Asian firms are either family-controlled or statecontrolled which makes their ownership traditionally concentrated since their establishments (Shakir, 2008). In transition economies like India, concentrated ownership is also gradually considered as a part of important internal governance mechanism (Abbas et al., 2013) towards principals-agents agency crisis and for mitigating other governance issues. Now, ownership concentration can have two types of influences on the corporate governance and performance of Indian firms.

Page $2 / 21$ 
Firstly, they may safeguard the interest of shareholders fraternity as a whole by promoting the wealth maximization objective through better monitoring management and limiting their opportunistic behaviour as proposed by the efficient monitoring hypothesis. Conversely, as per the proposition of expropriation hypothesis (Fama and Jensen, 1983; Shleifer and Vishny, 1997; Morck and Yeung, 2003; Roe, 2004; Burkart and Panunzi, 2006), these large owners can be self-servicing and thereby expropriate the minority shareholders and unjustifiably extract more benefits at their costs and consequently causes unfavourable impact on firms' financial performance.

Under this conceptual background, an inquiry into the effect of composition and concentration of ownership on firm valuation in context of an emerging market like India would really foster incremental value to the existing set of literatures in the domain of corporate finance and governance of emerging market economies. Firstly, the topic relating to the effect of ownership structure on firm value is much more debated in developed markets of U.S. and U.K and very limitedly in emerging markets like India. In India where we get a traditionally concentrated ownership pattern along with large diversion in forms of ownership, a fresh evidence produced by this study would be really worthwhile for the corporate policy makers. Secondly, limited number of researches (for example, Demsetz and Villalonga, 2001; Welch, 2003; Minguez-Vera and Martin-Ugedo, 2007; Tsai and Gu, 2007; Altaf and Shah, 2018) have considered the dynamism of this relationship and the issue of controlling for endogeneity in ownership-firm valuation relationship. This study by introducing dynamic panel data model and considering the endogeneity issue can significantly overcome the ignored limitations of previously considered static approaches of panel data analysis.

The rest of this article is divided into four sections with some sub-sections as per requirement. Section 2 contains a brief review of theoretical conception and empirical evidences. Section 3 of this article presents a detail description on the data, construction of variables, statistical and econometric tests adopted to arrive at the results. Section 4 reports the empirical results and findings. Section 5 concludes the study with some suggestions, policy recommendations, limitations and future research directions.

\section{Literature Review And Hypotheses Development}

There is an empirically endorsed theoretical perception that the various forms of ownership have important implications on the efficiency, performance and value of a firm (Brickley, et al., 1988; Pound, 1988; Kaur and Gill, 2009; Ting, 2013; Mishra and Kapil 2017; Pandey and Sahu, 2017). Under ownership structure, the impact of institutional ownership on firm performance and value is viewed under three hypotheses: efficient-monitoring hypothesis, conflict-of-interest hypothesis and strategic-alignment hypothesis (Pound, 1988). The efficient-monitoring hypothesis views institutional investors to have greater interest, incentive and expertise in monitoring management than individual shareholders. As part of monitoring, institutional investors also force managers in increasing firms' operational efficiency through increased expenditures in research and development activities and many more dimensions of firms' business operations. The efficient monitoring hypothesis is endorsed by a number of empirical evidences across different markets' context like McConnell and Servaes (1990) on U.S. firms, Douma et al. (2006), Pandey and Sahu (2019a) in context of India, Sahut and Gharbib (2010) in context of French market, Striewe et al. (2013) on Real Estate Investment Trust of U.S., Ting (2013) on Taiwan market etc. Conversely, in line with conflict-of-interest hypothesis Heard and Sherman (1987) and Pound (1988) opine that, in view of other profitable business relationships with the firm, institutional investors are sometimes coerced to vote and support the whims and fancies of management which have a detrimental effect on firm value. Again, the strategic-alignment hypothesis states that institutional investors and managers find it mutually advantageous to cooperate and maintain mutual understanding (Bhattacharya and Graham, 2007). Generally, such cooperation and mutual understanding reduce the beneficial effects on the firm value that could result from monitoring by large shareholders. Therefore, the conflict-of-interest hypothesis and the strategic-alignment hypothesis predict an unfavourable impact of institutional ownership on firm value. Coming into the Indian context, Kumar (2004) establishes a nonlinear relationship between these variables where financial institutions with at least 15 percent of ownership stake are seen to have efficient monitoring role on the BSE listed manufacturing firms of India. Subsequently, the study of Ghosh (2007) makes an in-depth analysis on the impact of institutional ownership especially of banks on the quality of monitoring and governance of managerial activities. The study after controlling the effect of exogenous variables suggests the existence of a complementary monitoring effect between banks and the managerial group. Besides, the increased external monitoring by

Page $3 / 21$ 
banks is also simultaneously raising the incentive for the managers to engage in internal monitoring. However, Khan (2008) doesn't find evidence on the role of institutional investors, like mutual funds and pension funds in ensuring effective corporate governance and monitoring of management of Indian companies.

Besides institutional shareholding, the role of promoters in influencing firms' performance and value has also been a central area of inquiry for some of the studies. Chakrabarti (2005) in context of Indian corporate sector highlights the pyramiding and tunneling effect of promoters' ownership in a firm. Pant and Pattanayak (2007) endorses the positive impact of foreign promoter ownership on the value of Indian companies. Unlike above two studies, Saravanan (2009) documents no significant impact of ownership type including promoters' ownership on the value of Indian firms. Again, Tawiah et al. (2015) using 125 observations of 25 listed companies out of Nifty 50 companies for the period of 2009-13, finds an inverse relationship between promoters' ownership and shareholders' wealth. Again, the study of Manna et al. (2016) also goes in line with the findings of Pant and Pattanayak (2007) and finds a positive impact of foreign promoters' ownership on the value of Indian firms. Most recently, Mishra and Kapil (2017) in a study of 391 Indian companies out of CRISIL NSE Index (CNX) 500 companies listed on National Stock Exchange (NSE) finds a significant and positive association between promoter ownership and Tobin's Q. The study also shows how the ownership of promoters affects performance of the firms differently at different levels of such ownership.

Under this premise, the present study frames the following hypothesis:

\section{Hypothesis 1}

Composition of ownership has significant effect on the value of Indian manufacturing firms.

The debate on the linkage between ownership concentration and firm value roots back to the landmark study of Berle and Means (1932) followed by Chandler (1962), which says when the shares of a publicly traded company is highly concentrated to a few hands, it provides them sufficient power to guide and administer the management functions and decisions, leads to reduced agency costs and enhanced firm performance and value. In subsequent stages, the functions of concentrated shareholders are viewed in two different perspectives under two hypotheses: efficient monitoring hypothesis and expropriation hypothesis. As per the first hypothesis, large owners may be more capable of monitoring and controlling the management of affairs of a company by exercising their substantial voting rights in the company. Being consistent with the efficient monitoring hypothesis, researchers like Shleifer and Vishny (1986) and Friend and Lang (1988) see ownership concentration as a source of internal governance mechanism and evidence increase in firm value with increase in the proportion of concentrated ownership. Researchers like Grossman and Hart (1986), Huddart (1993), and Denis and McConnell (2003) later on, justify this with the fact that, large shareholders have more incentives and prerogative to rigorously monitor management, restrain managerial opportunism and influence decision-making than the minority one who owns just a little proportion of the firm's equity. Conversely, researchers like Shleifer and Vishny (1997), La Porta et al. (1999), Burkart and Panunzi (2006) endorse the expropriation hypothesis which postulates that large owners can expropriate the minority shareholders and extract more benefits at their costs. This can happen in various ways such as diverting firm resources/assets through self-dealing transactions (Johnson et al., 2000), tunneling one firm's resources to another firm having varied controlling stake and cash flow rights (Bertrand et al., 2002) etc. Fama and Jensen (1983) and Earle et al. (2005) also suggest a negative impact of ownership concentration on firm valuation. Furthermore, Miguel et al. (2004) in context of Spanish firms document a non-linear (inverted U-shaped) relationship between ownership concentration and firm value. The study finds firm value of Spanish firms to increase at low level of concentration as a result of the monitoring effect and decreases with ownership concentration at high levels due to expropriation effect. Latter on studies form different country perspective like Ma and Tian (2014) in context of China, Vintila et al. (2014) in context of Romania also endorse a non-linear relationship between ownership concentration and firm value. Moreover, the studies like Demsetz (1983), McConnell and Servaes (1990), Brendea (2014) even document an insignificant relationship between these variables.

Notably, the studies on ownership concentration and firm value provide equivocal findings in context of India. Goswami (2002) gives evidence on subversive behaviour of large owners with minority owner and of depriving them from exercising their de jure 
ownership rights. Kumar and Singh (2013) evidence a non-linear relationship between ownership concentration and Tobin's in context of India. The study suggests a threshold of above 40 percent ownership to exert favourable impact on firm valuation as a result of better aligned interest whereas ownership stake less than that may cause entrenchment effect in Indian firms. Mittal and Anjala (2018) studies 178 non-financial Indian companies listed on NSE and evidence a positive and significant impact of ownership concentration on firm performance and value. However, we have fresh evidences from Altaf and Shah (2018) which endorses an inverted U-shaped relationship between ownership concentration and market performance of Indian firms.

Thus, literatures on ownership concentration and firm value give us mixed evidences in context of India and other economies. Where in case composition of ownership the evidence of non-linearity in relationship is very limited (e.g. Kumar, 2004), the studies on ownership concentration in different countries perspective evidence both linear as well as non-linear relationship and even no relationship between the variables. In this premise, the present study finds it more logical to assume a non-linear relationship between the variables and accordingly frames the following hypothesis:

\section{Hypothesis 2}

The relationship between ownership concentration and firm value is non-linear.

\section{Research Methodology 3.1. Sample Design}

For the purpose of the study, a set of strongly balanced panel data consisting 112 manufacturing firms of BSE 200 index of India for the period of 2011 to 2018 are collected from financial database software namely Capitaline Plus and 'ACE Equity' developed by Capital Market Publishers Pvt. Ltd and Accord Fintech Pvt. Ltd. respectively. Further, the study also uses annual reports of the sample firms for different financial years. The study sets a range of $\bar{x} \pm 2 \sigma$ (where $\bar{x}$ and $\sigma$ stand for the sample mean and standard deviation of each variable respectively) to eliminate the outliers from the panel dataset to avoid distorted results. However, we confine our study to manufacturing firms mainly because, the financial statements as a whole, capital structure, assets structure, working capital requirement etc. of service sector firms, especially, financial institutions are substantially different from that of other firms. Hence, inclusion of such firms would reduce uniformity and comparability of financial data across firms and results obtained thereby can't be logically generalised for all the firms. Secondly, unlike other emerging Asian economies, concentration of ownership is much more prominent in manufacturing sectors in case of India (Selarka, 2005; Altaf, 2016). Hence, studies on ownership concentration in particular reasonably prefer manufacturing firms as the study sample.

\subsection{Description of Variables}

\section{Ownership of domestic promoters}

Ownership of domestic promoters is measured by the percentage of ownership stake held by the Indian promoters. The domestic promoters, by virtue of their considerable ownership rights, experience and expertise, are supposed to exert positive influence on the financial performance of firms by actively monitoring the activities of management.

\section{Ownership of foreign promoters}

Quite similar to the domestic one, a foreign promoter is also supposed to be highly aware, knowledgeable and competent in monitoring the management of affairs of the firm which he/she invested in. By working as an active monitor of the management the foreign promoters are also supposed to influence the functioning and thereby financial performance of a corporation.

Ownership of institutional investors

Page 5/21 
The category of institutional shareholders consists of banks, non-banking financial institutions, mutual fund companies, insurance companies etc. These financial institutions keep professionally qualified and highly experienced investment experts who undertake great deal of efforts in terms of rigorous monitoring and active participation in the management of affairs of the invested company to ensure good return on their investments. Therefore, institutional shareholding is another component of firm ownership that influences it performance and valuation.

\section{Ownership of large shareholders}

It is measured by the sum of holdings of the shareholders with at least five percent stake. The present study follows Salerka (2005), Vintila et al. (2014), Brendea (2014) to set a threshold of five percent shareholding for considering a shareholder as large. Moreover, for the purpose of testing the non-linear relationship, the study, following Miguel et al. (2004), Vintila et al. (2014), considers the square term of total concentration denoted by Large_Own².

\section{Ownership of the largest shareholder}

In India, where most of manufacturing firms are family controlled (Selarka, 2005; Altaf, 2016) the largest owner plays the most dominative role in the management of affairs of companies. Recognizing the distinct importance of the largest shareholder, the study introduces this variable which represents the percentage of shareholding of largest shareholder in a particular firm for a particular year. To establish the non-linear relationship, the study following Vintila et al. (2014) again introduces the square term of this variable denoted by Largest_Own².

\section{Age}

Age of firms, both theoretically and empirically, is known to have very strong connection with their efficiency, level of profitability and valuation. Age of firms is correlated with operational efficiency and performance of firms in number of empirical studies like Katz (1982), Hannan and Freeman (1984), Loderer and Waelchli (2010) etc. Therefore, this variable should be considered while modelling the relationship between ownership structure and firm value.

\section{Liquidity}

The theory of corporate finance advocates important implications of firms' liquidity on operating efficiency and financial performance. The relationship is also sufficiently endorsed by number of empirical investigations like Saleem and Rehman, 2011; Niresh, 2012; Lartey et al., 2013 etc. This study takes firms' liquidity measured by quick ratio as a control variable.

\section{Assets utilization efficiency of firms}

The assets utilization efficiency is measured by asset turnover ratio which is derived from dividing annual sales by average total assets of firms. It represents how efficiently the management of a firm is utilizing its assets to generate sales (Ang et al., 2000) and thereby to enhance performance of firms. It also reflects the existence of agency problem between owners and managers and the monitoring efficiency of large owners towards easing out such problem. ATR has been used as a popular representative of agency problem in number of studies Li and Cui (2003), Matusin et al. (2014).

\section{Size}

Size of firms is an important control variable in modelling the relationship between ownership structure and firm performance. The firm size is used as a control variable in many important corporate governance studies like Farooque et al. (2007), Zeitun (2009), Maqbool and Zameern (2018).

\section{Leverage}

Firm financial leverage is also proved to be an important determinant of a firms' profitability and agency costs (Grossman and Hart, 1986; Jensen, 1986; Stulz, 1990, Pandey and Sahu, 2019b). Almost all of the studies which linked corporate governance 
parameters and corporate performance have considered firms' financial leverage (mostly in the form of debt to equity ratio) as control variable.

Firm value

This study represents firm value by Tobin's Q. Tobin's $Q$ is the most frequently used measure of firm valuation in most of the past studies like Morck et al. (1988), Demsetz and Villalonga (2001), Vintila et al. (2014), Mishra and Kapil (2017) etc.

Table 1

Description of Variables

\begin{tabular}{|c|c|c|}
\hline Variable & Acronym & Measurement \\
\hline $\begin{array}{l}\text { Ownership of } \\
\text { domestic promoters }\end{array}$ & ODP & Percentage of shares hold by the Indian promoters \\
\hline $\begin{array}{l}\text { Ownership of foreign } \\
\text { promoters }\end{array}$ & OFP & Percentage of shares hold by the foreign promoters \\
\hline $\begin{array}{l}\text { Ownership of } \\
\text { institutional investors }\end{array}$ & OIIN & $\begin{array}{l}\text { Percentage of shares hold by the institutional investors like banks, non-banking } \\
\text { financial institutions, mutual fund companies etc. }\end{array}$ \\
\hline $\begin{array}{l}\text { Ownership of large } \\
\text { shareholders }\end{array}$ & Large_Own & The sum of holdings of the shareholders with at least $5 \%$ stake \\
\hline $\begin{array}{l}\text { Ownership of largest } \\
\text { shareholder }\end{array}$ & Largest_Own & Percentage of share hold by the largest shareholder \\
\hline Age of firms & AGE & Age of the firm since establishment \\
\hline Firms' liquidity & QR & Ratio of quick assets to current liabilities \\
\hline $\begin{array}{l}\text { Assets utilization } \\
\text { efficiency of firms }\end{array}$ & ATR & Ratio of annual sales to average total assets \\
\hline Size of firms & FS & Natural logarithm of total assets \\
\hline Leverage ratio firms & LVR & Ratio of debt to equity capital \\
\hline Firm value & Tobin's Q & The ratio of market value of equity plus book value of debt to total assets \\
\hline $\begin{array}{l}\text { Lagged dependent } \\
\text { variable }\end{array}$ & Tobin's $Q_{i t-1}$ & One-year lagged Tobin's Q ratio \\
\hline Source: Prepared by & & \\
\hline
\end{tabular}

\subsection{Methodology}

The study first introduces static panel data model to establish the relationship between various forms as well as concentration of ownership and firm value. The static panel data model includes three regression models namely, Ordinary Least Square Model (OLS), Fixed Effect Model (FEM) and Random Effect Model (REM). The analysis also includes the selection of best fit regression model among these three models, because in panel data analysis it largely influences conclusions on the individual coefficients. In panel data, when the number of cross-sectional units is very larger than the number of time-series units, as in the present case, the estimates obtained by the FEM and REM differ significantly. Besides, all these three regression models have different underlying assumptions. The OLS model assumes the intercept as well as the slope coefficients to be same for all the 112 sample firms taken in the study. The FEM allows the intercepts to vary across the firms to incorporate special characteristics of the cross-sectional units. Finally, the REM assumes the intercept of a particular firm to be a random drawing from a large population which varies non-systematically with a constant mean value. As all these three conditions can't prevail simultaneously, so the study needs to select an appropriate model for regression. The study introduces restricted-F test, 
Breusch-Pagan Lagrange Multiplier test suggested by Breusch and Pagan's (1980) and Hausman test suggested by Hausman (1978) to have a selection among the three regression models. The estimated model would be in the following form:

Tobin's $Q_{i t}=a+\gamma_{1}(O D P)+\gamma_{2}(O F P)+\gamma_{3}(O I I N)+\gamma_{4}($ Large_Own $)+\gamma_{5}\left({\left.\text { Large_O } w n^{2}\right)}^{2}+\gamma_{6}(\right.$ Largest_Own $)+\gamma_{7}\left(\right.$ Largest_O $\left._{-} n^{2}\right)+$ $\beta_{1}(A G E)+\beta_{2}(F S)+\beta_{3}(Q R)+\beta_{4}(A T R)+\beta_{5}(L V R)+\varepsilon_{i t}$

Here, Tobin's $Q_{i t}$ refers to market value of $i_{\text {th }}$ firm at time period t, a represents the constant term, $\gamma_{1}$ to $Y_{7}$ represent the coefficients of ownership composition and concentration variables respectively, $\beta_{1}$ to $\beta_{5}$ represents the coefficients of the control variables and $\varepsilon_{i t}$ represents the error term.

Besides, considering the dynamism of the relationship and bias caused by potential endogeneity of the explanatory variables the study introduces Arellano-Bond (1991) dynamic panel estimation technique that determines the joint effects of the explanatory variables on the explained variable while controlling for potential bias due to endogeneity of the explanatory variables including the lagged dependent variable. The dynamic panel data model is mostly preferred when the number of cross-section units is larger than that of time series units, as in the present case. This is because of the fact that, the estimation methods don't require larger time periods to obtain consistent parameter estimates (Mishra, 2008). The dynamic panel data regression model includes lagged dependent variable as one of the independent variable with the supposition that, the lagged dependent variable is correlated with the random disturbance term of the model and inclusion of it in the model accounts for the dynamic effects (Wintoki et al., 2012; Altaf and Shah, 2018). Notably, in such a situation when the lagged dependent variable is likely to be correlated with the error term of the model, the static panel data models like OLS and FEM become biased and thereby produce inconsistent estimates as these models largely ignore unobserved time-variant effects and the endogeneity of dependent variable.

Therefore, following the previous literatures we also take one year lagged Tobin's Q as one of the independent variable to uncover the dynamism of relationship and to take into account the effect of some unobservable historical factors on the current dependent variable (Wooldridge, 2009).

Although, some of the previous literatures have considered instrumental variable in estimating dynamic panel data model (Anderson and Hsiao, 1982; Bhargava and Sargan, 1983) but following Mishra (2008) we adopt Arellano-Bond (1991) dynamic panel model which is based on Generalised Method of Moments (GMM). Besides, according to Ahn and Schmidt (1995) GMM estimator is likely to convey more information on data during the course of estimation than the method of instrumental variables. In GMM method we control the potential bias due to endogeneity of independent variables by taking one year lagged value of the lagged dependent variable and other independent variables as instruments (Basant and Mishra, 2013).

Additionally, the study introduces Arellano-Bond test for autocorrelation and Sargan test (1985) of over-identification to check the presence of autocorrelation and validity of the instruments used in the model respectively.

Notably, there are two versions of Arellano-Bond estimator namely one step and two step estimator. The asymptotic standard errors of one step estimator are unbiased and more reliable to draw inferences on the individual coefficients but at the same time, under this estimation the Sargan test over-rejects the null-hypothesis of over-identification restriction in the presence of heteroskedasticty. Moreover, the robust standard error under one-step estimation can largely control the problem of heteroskedasticity but it can't produce the Sargan statistic. Therefore, we execute both the estimations wherein we consider the individual coefficients of one-step estimation with robust standard error to draw inferences and the statistics of two-step estimation like Sargan statistic, Wald-Chi ${ }^{2}$ statistic to check the over-identification restriction and overall significance of the model. In nutshell, recognising the dynamism of the relationship and the issue of endogeneity we extend our analysis from static approach to dynamic approach which ultimately leads us to most robust estimates and thereby strong inferences.

\section{Data Analysis}

\subsection{Summary Statistics}


The descriptive statistics of all the variables can be obtained from Table 2. Starting from the composition of ownership of the sample firms, it is observed that the largest part i.e. about 45 percent of ownership of Indian manufacturing firms goes to domestic promoters, whereas the institutional investors form the second largest category of investor with an average ownership of 27.77 percent. However, the foreign promoters hold a small part of ownership in the firms. The firm level average total ownership concentration is found to be 50.79 percent with a maximum value of 88.54 . It indicates that, a large part of ownership in Indian manufacturing firms is of concentrated in nature. Again, a standard deviation of 17.06 indicates low level of difference in term s of ownership concentration across firms in the sector. Besides, the average ownership of the largest owner is found to be 33.64 with a maximum value of 98.38 . This signifies the dominance of the largest owner and thereby relevancy behind separate treatment of largest owner as an ownership concentration variable in this study.

So far as the value generating ability of such firms is concerned, the average value of the variable Tobin's $Q$ is found to be 2.39 with a standard deviation of 1.91. It indicates that, though the value generating abilities of the sample firms are considerably different but on an average the market value of Indian manufacturing firms is more than two times of their book value.

Table 2

Summary Statistics

\begin{tabular}{|lllll|}
\hline Variable & Mean & Standard Deviation & Minimum Value & Maximum Value \\
\hline ODP & 45.43 & 23.37 & 0.00 & 90.44 \\
\hline OFP & 2.94 & 8.35 & 0.00 & 39.70 \\
\hline OIIN & 27.77 & 11.61 & 3.03 & 53.17 \\
\hline Large_Own & 50.79 & 17.06 & 14.55 & 88.54 \\
\hline Largest_Own & 33.64 & 21.63 & 5.63 & 98.38 \\
\hline AGE & 41 & 20 & 3 & 94 \\
\hline QR & 1.53 & 1.65 & 0.13 & 22.42 \\
\hline ATR & 1.14 & 0.54 & 0.02 & 2.58 \\
\hline FS & 9.14 & 1.32 & 5.71 & 12.06 \\
\hline LVR & 0.59 & 0.53 & 0.00 & 3.26 \\
\hline Tobin's Q & 2.39 & 1.91 & 0.35 & 10.62 \\
\hline Source: Calculated by Authors & & \\
\hline
\end{tabular}

\subsection{Test of Multicollinearity}

The presence of multicollinearity property among the variables can produce erroneous result and lead to spurious inferences. So, it is highly useful to check the existence of such data property before panel data regression analysis. For the purpose, the study introduces VIF test (Table 3) where the maximum VIF value is found to be 4.28 followed by 4.12 . Regarding multicollinearity there is no standard criterion for determining the bottom line of the tolerance value of VIF but according to Gujarati (2004), explanatory variables can be regarded as highly collinear if the VIF value exceeds 10 . Therefore, our explanatory variables are free form multicollinearity. To confirm such property, the study again introduces pair-wise correlation matrix (Table 3) and finds no such serious multicollinearity between any pair of independent variables. 
Table 3

Pair-wise Correlation Matrix and Variance Inflation Factor

\begin{tabular}{|c|c|c|c|c|c|c|c|c|c|c|c|}
\hline $\begin{array}{l}\text { Independent } \\
\text { Variables }\end{array}$ & ODP & OFP & OIIN & Large_Own & Largest_Own & AGE & QR & ATR & FS & LVR & VIF \\
\hline ODP & 1 & & & & & & & & & & 4.28 \\
\hline OFP & $-0.35^{\star}$ & 1 & & & & & & & & & 2.38 \\
\hline OIIN & $-0.38^{\star}$ & $-0.14^{*}$ & 1 & & & & & & & & 3.15 \\
\hline Large_Own & $0.42^{*}$ & -0.02 & $-0.48^{*}$ & 1 & & & & & & & 4.12 \\
\hline Largest_Own & $0.34^{*}$ & -0.03 & $-0.37^{*}$ & $0.34^{*}$ & 1 & & & & & & 3.05 \\
\hline AGE & $-0.16^{*}$ & -0.03 & $0.13^{*}$ & $-0.07^{\star \star}$ & $0.07^{\star \star}$ & 1 & & & & & 1.14 \\
\hline QR & $0.08^{\star \star}$ & -0.04 & 0.04 & 0.01 & 0.01 & -0.04 & 1 & & & & 1.18 \\
\hline ATR & $-0.19^{\star}$ & $0.24^{*}$ & $-0.11^{*}$ & $0.07^{\star \star \star}$ & $0.07^{\star \star \star}$ & 0.06 & $0.23^{*}$ & 1 & & & 1.37 \\
\hline FS & $-0.08^{\star \star}$ & $-0.14^{*}$ & $0.24^{*}$ & $-0.06^{\star \star \star}$ & $-0.07^{\star \star \star}$ & -0.01 & -0.02 & $-0.33^{*}$ & 1 & & 1.51 \\
\hline LVR & -0.00 & -0.01 & -0.05 & $-0.21^{*}$ & $-0.21^{*}$ & $-0.15^{\star}$ & $-0.19^{*}$ & -0.03 & $0.19^{\star}$ & 1 & 1.40 \\
\hline \multicolumn{12}{|c|}{ Note: ${ }^{*}$ Significant at 1 per cent level ${ }^{* \star}$ Significant at 5 per cent level ${ }^{* \star *}$ Significant at 10 per cent level } \\
\hline
\end{tabular}

\subsection{Results and Findings}

The study after confirming the non-existence of multicollinearity proceeds to panel data regression analysis. Among the three regression models, the F-statistic of OLS and FEM and the Wald- $\chi 2$ statistic of REM is found to be significant at 1 percent level (Table 4). Furthermore, the restricted F-test statistic $[F(74,426)=8.57 *]$, BP-LM test statistic $[X 2(1)=299.77 *]$ and Hausman test statistic $\left[X 2(12)=59.10^{\star}\right]$ are all found to be significant at 1 percent level of statistical significance (Table 5). The restricted $\mathrm{F}$ test chooses FEM over OLS, the BP-LM test chooses REM over OLS and the Hausman test selects FEM over REM. Therefore, we find FEM as the best fit regression model for establishing relationship between the variables. 
Table 4

Panel Regression Results (Dependent Variable: Tobin's Q)

\begin{tabular}{|c|c|c|c|c|c|c|}
\hline \multicolumn{3}{|c|}{ Ordinary Least Square Model } & \multicolumn{2}{|c|}{ Fixed Effect Model } & \multicolumn{2}{|c|}{ Random Effect Model } \\
\hline & Coefficient & t-Stat & Coefficient & t-Stat & Coefficient & z-Stat \\
\hline Intercept & -1.015 & -0.84 & -0.939 & -0.49 & -2.176 & -1.51 \\
\hline ODP & 0.077 & $8.58^{\star}$ & 0.018 & 0.87 & 0.073 & $6.28^{*}$ \\
\hline OFP & 0.084 & $7.29^{\star}$ & 0.047 & $1.68^{\star \star \star}$ & 0.097 & $5.83^{*}$ \\
\hline OIIN & 0.039 & $3.68^{*}$ & 0.023 & $1.71^{\star \star \star}$ & 0.037 & $3.24^{*}$ \\
\hline Large_Own & -0.031 & -0.89 & -0.033 & $-5.30^{\star}$ & -0.035 & -1.14 \\
\hline Large_Own² & 0.0003 & 0.69 & 0.0003 & $2.10^{\star \star}$ & 0.0004 & 0.41 \\
\hline Largest_Own & -0.009 & -0.47 & -0.087 & $-2.78^{\star}$ & -0.025 & -1.08 \\
\hline Largest_Own² & -0.0004 & -1.64 & 0.001 & $2.92^{*}$ & -0.00005 & -0.17 \\
\hline AGE & -0.004 & -1.42 & 0.163 & $3.91^{*}$ & 0.0007 & 0.10 \\
\hline QR & 0.054 & 0.84 & 0.122 & $1.92^{\star \star}$ & 0.063 & 1.01 \\
\hline ATR & 0.576 & $4.33^{\star}$ & 0.768 & $3.06^{*}$ & 0.860 & $4.71^{*}$ \\
\hline FS & -0.0009 & -0.01 & -0.302 & -1.21 & 0.173 & $1.69^{\star \star \star}$ \\
\hline LVR & -1.149 & $-8.19^{\star}$ & -0.861 & $-4.14^{*}$ & -1.174 & $-6.63^{*}$ \\
\hline F-Stat & $20.32^{*}$ & & $10.17^{\star}$ & & & \\
\hline Wald- $\chi 2$ & & & & & $149.61^{*}$ & \\
\hline $\mathrm{R}^{2}$ & 0.438 & & 0.223 & & 0.154 & \\
\hline \multicolumn{7}{|c|}{ Note: ${ }^{*}$ Significant at 1 per cent level ${ }^{* \star}$ Significant at 5 per cent level ${ }^{* \star \star}$ Significant at 10 per cent leve } \\
\hline
\end{tabular}


Table 5

Selection of Appropriate Model

\begin{tabular}{|c|c|c|c|}
\hline Purpose & Null Hypothesis & Test & Test Statistic \\
\hline \multirow[t]{2}{*}{ Ordinary Least Square Model Vs Fixed Effect Model } & \multirow[t]{2}{*}{ All $u_{i}=0$} & Restricted & \multirow[t]{2}{*}{$F(74,426)=8.57^{*}$} \\
\hline & & F Test & \\
\hline \multirow[t]{2}{*}{ Ordinary Least Square Model Vs Random Effect Model } & \multirow{2}{*}{$\sigma^{2}{ }_{u}=0$} & Breusch-Pagan & \multirow[t]{2}{*}{$\chi 2(1)=299.77^{*}$} \\
\hline & & Lagrange Multiplier Test & \\
\hline \multirow[t]{3}{*}{ Fixed Effect Model Vs Random Effect Model } & Difference in & Hausman & \multirow[t]{3}{*}{$\chi 2(12)=59.10^{*}$} \\
\hline & coefficients is & Test & \\
\hline & not systematic & & \\
\hline \multicolumn{4}{|l|}{ Note: ${ }^{*}$ Significant at 1 per cent level } \\
\hline Source: Calculated by Authors & & & \\
\hline
\end{tabular}

Based on the results of FEM, the study finds no evidence on the impact of ODP on the value of Indian manufacturing firms. However, the study finds statistically significant and positive (though not so strong) relationship between OFP and OIIN on the value of such firms measured by Tobin's Q. So, results of FEM model are quite consistent with our first hypothesis that assumes a significant effect of ownership composition on the value of our sample firms.

Further, the study finds both the measures of ownership concentration to have a non-linear relationship with the value of Indian manufacturing firms measured by Tobin's Q. While the coefficients for both the measures of ownership concentration i.e. Large_Own $\left[-0.033(-5.30)^{\star}\right]$ and Largest_Own $\left[-0.087\left(-2.78^{\star}\right)\right]$ are found to be negative and significant at 1 percent level respectively, the coefficients of their squared terms are found to be significantly positive. The result in this regard suggests a negative impact of ownership concentration on the firm valuation till a certain point of concentration which endorses the idea of expropriation effect arising out of both the forms of ownership concentration and thereafter, a positive impact at higher level of concentration due to active monitoring by the majority shareholders as a whole and the largest shareholder alone. Therefore, this result (U-shaped relationship) supports our second hypothesis which assumes a non-linear relationship between ownership concentration and value of Indian manufacturing firms.

However, as we already discussed in the sub-Sect. 3.3 that the fixed effect model as a static panel data analysis can't control the potential bias that arises due to endogeneity problem and therefore the results produced under this model must not be treated as robust. Therefore, to consider the dynamism of relationship and to eliminate the bias caused by potential endogeneity of the explanatory variables including the lagged dependent variable we estimate the Arellano-Bond (1991) dynamic panel estimation technique. The dynamic panel regression model including one-step and two-step estimations are presented in Table 6. The Arellano-Bond (1991) dynamic panel estimation also includes test for the validity of the instruments used and autocorrelation problem in the model used. The Sargan test for over-identification statistic is found to be insignificant [8.101 $(p=0.15)]$ implying that our estimation models do not suffer from the problem of over-identification restrictions. The underlying null-hypothesis of the test can't be rejected which means the instrument used in the estimations are valid, implying that these instruments are not correlated with the error term (Mahakud and Misra, 2009). 
Table 6

Results of Arellano Bond Dynamic Panel Data Model

\begin{tabular}{|c|c|c|c|c|}
\hline \multirow[t]{2}{*}{ Variables } & \multicolumn{2}{|c|}{ One Step Estimates } & \multicolumn{2}{|c|}{ Two Step Estimates } \\
\hline & Coefficient & z-Stat & Coefficient & z-Stat \\
\hline Intercept & 7.796 & $3.62^{*}$ & 8.128 & $4.20^{*}$ \\
\hline Tobin's $Q_{i t-1}$ & 0.202 & $2.34^{\star \star}$ & 0.244 & $6.00^{\star}$ \\
\hline ODP & 0.016 & $1.92^{\star \star}$ & 0.005 & $2.08^{\star \star}$ \\
\hline OFP & 0.071 & $2.69^{\star}$ & 0.061 & $2.34^{\star \star}$ \\
\hline OIIN & 0.031 & $2.11^{\star \star}$ & 0.029 & $2.08^{\star \star}$ \\
\hline Large_Own & -0.056 & $-1.92^{\star *}$ & -0.035 & $-2.16^{\star \star}$ \\
\hline Large_Own² & 0.0004 & $2.63^{*}$ & 0.0002 & $4.13^{*}$ \\
\hline Largest_Own & -0.073 & $-2.21^{\star \star}$ & -0.029 & $-2.85^{*}$ \\
\hline Largest_Own² & 0.0007 & $2.70^{\star}$ & 0.0004 & $1.96^{\star \star}$ \\
\hline AGE & 0.157 & $2.77^{\star}$ & 0.072 & 1.49 \\
\hline QR & -0.196 & $-2.73^{*}$ & -0.133 & $-1.93^{*}$ \\
\hline ATR & -0.074 & -0.19 & 0.210 & 0.58 \\
\hline FS & -1.173 & $-3.66^{*}$ & -0.998 & $-3.53^{*}$ \\
\hline LVR & -1.073 & $-4.17^{*}$ & -0.939 & $-3.92^{*}$ \\
\hline Wald-Chi ${ }^{2}$ & $83.67^{\star}$ & & $152.11^{*}$ & \\
\hline Sargan Test for over-identification & & & $8.101(p=0$ & \\
\hline Arellano Bond Test for AR (1) & $1.047(p=0.29)$ & & $0.869(p=0$ & \\
\hline Arellano Bond Test for AR (2) & $-1.334(p=0.18)$ & & $-1.194(p=c$ & \\
\hline \multicolumn{5}{|c|}{ Note: i. * Significant at 1 per cent level ** Significant at 5 per cent level } \\
\hline \multicolumn{5}{|c|}{$\begin{array}{l}\text { ii. z-statistics in one step estimation are based on robust-standard error to control for heteroskedasticity and } \\
\text { autocorrelation }\end{array}$} \\
\hline Source: Calculated by Authors & & & & \\
\hline
\end{tabular}

Besides, the Arellano-Bond tests of both AR (1) and AR (2) are found to be insignificant which implies that our models are free from autocorrelation problem. Again, the highly significant Wald-Chi ${ }^{2}$ statistics of both the models confirm that both the models are statistically significant. We already mentioned that, the z-statistics of regression coefficients produced by step-one are based on robust standard error and hence we only consider these coefficients for the purpose of testing our hypotheses and drawing subsequent inferences. The study first notes that the lagged dependent variable of our models denoted by Tobin's $\mathrm{Q}_{\mathrm{it}-1}$ representing previous year firm value has significant impact on the of current period's firm value. Regarding various forms of ownership, the results of step-one estimation of Arellano-Bond dynamic panel data model documents a statistically significant and positive affect of all the forms of ownership and the value of Indian manufacturing firms. So, our dynamic panel data model based on GMM reports slightly different results from the FEM estimations. The coefficient of ODP, which is 
found to be insignificant in the earlier model, is found positive and significant in our one-step estimation of dynamic panel data model. So, the GMM results remain much consistent with our first hypothesis which assumes a significant impact of various forms of ownership on the value of Indian manufacturing firms. Our results in this regards endorse the efficient monitoring hypothesis on ownership structure which postulates a favourable impact of promoters and institutional ownership on the efficiency and financial performance of firms as a result of reduced owners-managers agency crisis through active monitoring of the management by such shareholders. Hence, the previously documented favourable impact of promoter ownership on the financial performance and value of Indian firms by Pant and Pattanayak (2007), Manna et al. (2016), Mishra and Kapil (2017) are found to be consistent with our findings. Regarding institutional type of ownership and firm valuation our findings go in line with the studies of Douma et al. (2006), Ghosh (2007) in context of Indian market and McConnell and Servaes (1990) on U.S. market context, Sahuta and Gharbib (2010) in context of French firms, Ting (2013) on Taiwan market etc. Therefore, unlike Bhattacharya and Graham (2007) in context of Finland, the present study approves that the conflict-of-interest hypothesis and strategic-alignment hypothesis are not found to be operational in the relationship between institutional type of ownership and valuation of Indian manufacturing firms.

Regarding ownership concentration the Arellano-Bond (1991) dynamic panel estimation reports largely consistent results with FEM estimation. In both the estimations i.e. without consideration of endogeneity and unobserved heterogeneity issue in FEM model and consideration of the issues in Arellano-Bond model, the two variables used for ownership concentration are found to have a non-linear relationship with Tobin's Q. Where the coefficients of Large_Own $\left[-0.056\left(z=-1.92^{* \star}\right)\right]$ and Largest_Own $\left[-0.073\left(z=2.21^{\star \star}\right)\right]$ are found to be negative and significant, the coefficients of their squared terms $\left[0.0004\left(z=2.63^{\star}\right)\right]$ and $\left[0.0007\left(z=2.70^{*}\right)\right]$ are found to be significantly positive. So, being consistent with the second hypothesis, our results finally confirms a U-shaped relationship between ownership concentration and firm value of Indian manufacturing firms. Now, to be more precise in our findings it is necessary to determine the threshold level of ownership concentration both for the large owners and the largest owner where the effects are actually getting shifted. The study determines the thresholds as below:

\subsection{Determination of Threshold Level of Large and Largest Ownership}

The study evidences a quadratic, especially, U-shaped relationship through estimating a non-linear model with a squared term of the independent variable. The quadratic curb for each dependent variable has only one breakpoint, which is optimally derived by taking the first differentiation with respect to ownership concentration.

The regression equation representing the quadratic relationship between the variables is as below:

$Y_{i}=a+\beta_{1} X_{i}+\beta_{2} X_{i}^{2}+$

Now, as per the condition of maximum threshold i.e. partial derivative would be equal zero, the threshold level of the independent variables Large_Own and Largest_Own can be derived by the following model:

$\boldsymbol{\beta}_{1}+2 \boldsymbol{\beta}_{2}$ Threshold of Large_Own / Largest_Own $=0$, where $\beta_{1}$ and $\beta_{2}$ are the two coefficients of the variable and carry opposite sign.

\section{or, Threshold of Large_Own / Largest_Own $=-\left(\beta_{1} / 2 \beta_{2}\right)$}

Applying this method in our dynamic panel data estimation the threshold levels of Large_Own and Largest_Own are determined and shown below: 
Table 7

Determination of Threshold Level of Ownership Concentration

\begin{tabular}{|lll|}
\hline Independent Variables & \multicolumn{2}{c|}{ Dependent Variable: Tobin's Q } \\
\cline { 2 - 2 } & Coefficient & Threshold $\left(\beta_{1} / 2 \beta_{2}\right)$ \\
\hline Large_Own & -0.056 & 70.00 \\
\hline Large_Own & \\
\hline Largest_Own & 0.0004 & \\
\hline Largest_Own & 52.14 \\
\hline Source: Calculated by Authors & \\
\hline
\end{tabular}

From Table 7 it is observed that, the ownership concentration measured by Large_Own and Largest_Own has non-linear effect on Tobin's Q. In line with the previous Indian evidence like Kumar and Singh (2013), the findings of this study suggests that at lower level of concentration the role of large owners and the largest owner in creating an internal governance mechanism remains marginal because of weakly aligned interests with the company but at higher level of concentration due to better alignment of interests the active monitoring effect is evidenced in the form of increased firm value. More specifically, this can also be inferred that ownership concentration, below a threshold of 70 percent for large owners and 52 percent for largest owner, can unfavourably impact firm value as a consequence of joint effect of misaligned interest and expropriation. However, previous studies like Altaf and Shah (2018) produce quite different evidence that at expropriation effect starts playing only at a higher level of concentration as a result of likely shifting agency crisis from owners-mangers conflict of interest to majorityminority owners' conflict of interest. But, contrary to that, the present study evidences the expropriation effect to play at lower level of concentration. Notably, after a certain threshold of concentration although the positive impact is evidenced but the study cannot sensibly deny the presence of expropriation thereafter with active monitoring effect with the later overweighing the effect of the former. The findings on the non-linearity effect of Large_Own and Largets_Own are graphically presented by Fig. 1 and Fig. 2.

\section{Summary And Conclusions}

The study aims at establishing the impact of composition and concentration of ownership and the value of 112 BSE listed Indian manufacturing firms for the period of 2011 to 2018. The study first introduces static panel data estimation technique to establish the relationship. However, considering the dynamism of relationship and the potential bias caused by endogeneity and unobserved heterogeneity, the study adopts Arellano-Bond (1991) dynamic panel data estimation technique based on Generalised Methods of Moment as an alternative estimation approach to arrive at robust results. Notably, the robust results obtained from the dynamic panel data estimation largely remain consistent with the estimation of static panel data model. Based on the results obtained from both the panel data estimation approaches, the study concludes a positive impact of various forms of ownership on the value of Indian manufacturing firms. In this regard, the study findings become consistent with the efficient monitoring hypothesis of ownership structure which proposes a favourable impact of promoters and institutional types of ownership on the financial performance of corporations. Regarding the ownership concentration, the study finds an inverted-U shaped relationship between both the forms of concentration, viz-a-viz, the ownership by the largest owner and total concentration in the hands of majority or large shareholders (shareholders holding at least five percent stake) and the value of Indian manufacturing firms. In line with some previous empirical findings of the present study also evidences an expropriation effect by the large and largest shareholder in Indian manufacturing firms which last up to a threshold of 70 percent for the former and 54 percent for the latter.

Inquiring into the root causes behind such expropriation in Indian firms we reach to some specific reasons as to why it is quite easy to abuse minority shareholders in India. Firstly, status of minority shareholders in India is largely different in compare to 
the developed economies' market like United States and United Kingdom. For instance, in USA, all major corporate decisions are initiated by the board itself and the majority shareholders hardly influence any of such corporate decisions of the board. The shareholders may change the course of the corporation only by replacing the board. Conversely, in India, a board follows the fundamental principle while taking the corporate decisions that the opinion of majority shall always prevail. Secondly, both the versions of Indian companies' act i.e. of 1956 and 2013 have prescribed more or less similar criteria for minority shareholders to apply to the National Company Law Tribunal (NCLT) or previously Company Law Board (CLB) in case they feel oppressed. As per the provision of companies act, a member/shareholder having less that 10 percent of ownership in companies issued share capital can't alone seek redressal from the tribunal in case he/she feel oppressed. In such case, a minimum of hundred members or 1/10th of total members whichever is lower, is required to apply to the tribunal. Most often than not, it becomes a cumbersome work for minority shareholders in India especially with less financial awareness and knowledge of legislation to comply with above stipulated criteria. Thirdly, the tribunal also shows reluctance to quickly interfere in internal corporate affairs with the caution that there may be unscrupulous shareholders who can take the undue advantage of the provisions through acting in pretext of investors' rights. Apart from these, there are a number of instances when courts in India act with the principle of non-interference and refuse to interfere in the management of a company. Finally, high cost, tedious and vexing legal procedure, less hope and instances of success and lack of education and legal awareness have also discouraged lay investors of India to initiate action against giant shareholders who are economically and politically enough powerful. So, the provisions on minority interest protection in India seem quite inaccessible and unrealistic for the lay investors and it becomes quite easy for the majority shareholders to reap benefit of the legal flows or regulatory loopholes.

However, it is indeed a good sign that although after a certain threshold but a favourable impact is found to be exerted by the largest shareholder on the financial performance of the sampled companies. Therefore, ownership concentration by the large and the largest owner at higher level is becoming a complementary force with the external institutional specifications and acting as an internal regulatory mechanism to dismantle the type I agency problem and improve firm performance.

The study based on its findings unable completely rely on the role of majority shareholders as an internal governance mechanism in the Indian manufacturing firms and accordingly suggests stricter external regulatory and institutional specificities as supplementary mechanism that could ensure better corporate governance and protection of minority shareholders interest as previously suggested by Kumar and Singh (2012), Hamid et al (2016), Altaf and Shah (2018). Besides, the study also recommends possible amendments in the corporate laws towards improving the legal status and redressal seeking power of the small investors in India.

To conclude, the study must admit that the findings and thereby drawn inferences of this study are valid for Indian manufacturing firms and for the considered time period only. Hence, further studies on other sectors, markets or for different time periods may reveal varied results. Moreover, the study strongly recommends sector-specific inquiries and even crosscountry investigations as future research avenues.

\section{Declaration}

\section{Competing interests}

The authors declare that they have no competing interests.

\section{Authors' contributions}

Specification of contribution by the authors is not applicable to this research. The whole study is conducted with joint efforts.

\section{References}

1. Abbas A, Naqvi HA, Mirza HH (2013) Impact of large ownership on firm performance: a case of non-financial listed companies of Pakistan. World Applied Sciences Journal 21(8):1141-1152

Page $16 / 21$ 
2. Ahn SC, Schmidt P (1995) Efficient estimation of models for dynamic panel data. J Econ 68(1):5-27

3. Altaf N (2016) Economic value added or earnings: what explains market value in Indian firms? Future Business Journal 2(2):152-166

4. Altaf N, Shah FA (2018) Ownership concentration and firm performance in Indian firms: does investor protection quality matter? Journal of Indian Business Research 10(1):33-52

5. Anderson TW, Hsiao C (1981) Estimation of dynamic models with error components. J Am Stat Assoc 76(375):598-606

6. Ang JS, Cole RA, Lin JW (2000) Agency costs and ownership structure. The Journal of Finance 55(1):81-106

7. Arellano M, Bond S (1991) Some tests of specification for panel data: Monte Carlo evidence and an application to employment equations. The Review of Economic Studies 58(2):277-297

8. Balasubramanian N (2010) Corporate governance and stewardship: emerging role and responsibilities of corporate boards and directors. Tata McGraw Hill, New Delhi

9. Barca F, Becht M (2002) The control of corporate Europe. Oxford University Press

10. Basant R, Mishra P (2013) Concentration and other determinants of innovative efforts in Indian manufacturing sector: A dynamic panel data analysis. Working Paper No. 2013-02-01, Indian Institute of Management, Ahmedabad

11. Bertrand M, Mehta P, Mullainathan S (2002) Ferreting out tunneling: an application to Indian business groups. Q J Econ 117(1):121-148

12. Bhargava A, Sargan JD (1983) Estimating dynamic random effects models from panel data covering short time periods. Econometrica: Journal of the Econometric Society 51(6):1635-1659

13. Bhattacharya PS, Graham M (2007) Institutional ownership and firm performance: evidence from Finland. School Working Paper-Accounting/Finance Series

14. Berle AA, Means GC (1932) The modern corporation and private property. Transaction, New Brunswick.

15. Brendea G (2014) Ownership structure, performance and capital structure of Romanian firms. Internal Auditing Risk Management 36(1):1-9

16. Breusch TS, Pagan AR (1980) The Lagrange multiplier test and its applications to model specification in econometrics. The Review of Economic Studies 47(1):239-253

17. Brickley JA, Lease RC, Smith CW (1988) Ownership structure and voting on antitakeover amendments. J Financ Econ 20:267-291

18. Burkart M, Panunzi F (2006) Agency conflicts, ownership concentration, and legal shareholder protection. J Financ Intermediation 15(1):1-31

19. Chakrabarti R (2005) Corporate governance in India: evolution and challenges. ICFAI Journal of Corporate Governance 4(4):50-68

20. Chandler AD (1962) Strategy and structure: chapters in the history of the American enterprise. Massachusetts Institute of Technology Cambridge

21. Coffee JCJ (1991) Liquidity versus control: the institutional investor as corporate monitor. Columbia Law Rev 91(6):12771368

22. Demsetz H (1983) The structure of ownership and the theory of the firm. The Journal of Law Economics 26(2):375-390

23. Demsetz H, Villalonga B (2001) Ownership structure and corporate performance. Journal of Corporate Finance 7(3):209233

24. Denis DK, McConnell JJ (2003) International corporate governance. J Financial Quant Anal 38(1):1-36

25. Douma S, George R, Kabir R (2006) Foreign and domestic ownership, business groups, and firm performance: evidence from a large emerging market. Strateg Manag J 27(7):637-657

26. Earle JS, Kucsera C, Telegdy Á (2005) Ownership concentration and corporate performance on the Budapest stock exchange: do too many cooks spoil the goulash? Corporate Governance: An International Review 13(2):254-264

27. Faccio M, Lang LHP (2002) The ultimate ownership of Western European corporations. J Financ Econ 65(3):365-395

Page $17 / 21$ 
28. Farooque OA, van Zijl T, Dunstan K, Karim AW (2007) Ownership structure and corporate performance: evidence from Bangladesh. Asia-Pacific Journal of Accounting Economics 14(2):127-149

29. Fama EF, Jensen MC (1983) Separation of ownership and control. The Journal of Law Economics 26(2):301-325

30. Franks J, Mayer C (1997) Corporate ownership and control in the UK, Germany, and France. Journal of Applied Corporate Finance 9(4):30-45

31. Friend I, Lang LH (1988) An empirical test of the impact of managerial self interest on corporate capital structure. The Journal of Finance 43(2):271-281

32. Ghosh S (2007) Bank monitoring, managerial ownership and Tobin's Q: an empirical analysis for India. Manag Decis Econ 28(2):129-143

33. Goswami O (2002) Corporate Governance in India, taking action against corruption in Asia and the pacific. Asian Development Bank), Manila, Chap. 9

34. Grossman SJ, Hart OD (1986) The costs and benefits of ownership: A theory of vertical and lateral integration. J Polit Econ 94(4):691-719

35. Gujarati DN (2004) Basic Econometrics, 4th edition, McGraw Hill

36. Hamid MA, Ting IWK, Kweh QL (2016) The relationship between corporate governance and expropriation of minority shareholders' interests. Procedia Economics Finance 35:99-106

37. Hannan MT, Freeman J (1984) Structural inertia and organizational change. Am Sociol Rev 49(2):149-164

38. Hausman JA (1978) Specification tests in econometrics. Econometrica: Journal of the Econometric Society 46(6):12511271

39. Heard JE, Sherman HD (1987) Conflicts of interest in the proxy voting system. Investor Responsibility Research Centre, Washington, DC

40. Heugens PP, Van Essen M, Van Oosterhout JH (2009) Meta-analyzing ownership concentration and firm performance in Asia: towards a more fine-grained understanding. Asia Pacific Journal of Management 26(3):481-512

41. Hill CW, Snell SA (1989) Effects of ownership structure and control on corporate productivity. Acad Manag J 32(1):25-46

42. Huddart S (1993) The effect of a large shareholder on corporate value. Manage Sci 39(11):1407-1421

43. Jensen MC (1986) Agency costs of free cash flow, corporate finance, and takeovers. Am Econ Rev 76(2):323-329

44. Johnson S, La Porta R, Lopez-de-Silanes F, Shleifer A (2000) Tunneling. Am Econ Rev 90(2):22-27

45. Katz R (1982) The effects of group longevity on project communication and performance. Adm Sci Q 27(1):81-104

46. Kaur P, Gill S (2009) Patterns of corporate ownership: evidence from BSE-200 index companies. Paradigm 13(2):13-28

47. Khan MAA (2008) Corporate governance and the role of institutional investors in India. J Asia-Pac Bus 7(2):37-54

48. Kumar J (2004) Does ownership structure influence firm value? Evidence from India. The Journal of Entrepreneurial Finance Business Ventures 9(2):61-93

49. Kumar N, Singh JP (2013) Effect of board size and promoter ownership on firm value: some empirical findings from India. Corporate Governance: The International Journal of Business in Society 13(1):88-98

50. Lartey VC, Antwi S, Boadi EK (2013) The relationship between liquidity and profitability of listed banks in Ghana. International Journal of Business Social Science 4(3):48-56

51. Leech D, Leahy J (1991) Ownership structure, control type classifications and the performance of large British companies. Econ J 101(409):1418-1437

52. Lemmon ML, Lins KV (2003) Ownership structure, corporate governance, and firm value: evidence from the East Asian financial crisis. The Journal of Finance 58(4):1445-1468

53. Li H, Cui L (2003) Empirical study of capital structure on agency costs in Chinese listed firms. Nature Science 1(1):12-20

54. Loderer C, Waelchli U (2010) Firm age and performance. MPRA Paper No. 26450, Available at: https://mpra.ub.unimuenchen.de/26450/1/age_performance.pdf, Retrieved on: 20.06.2018 
55. Ma S, Tian G (2009) Board composition, board activity and ownership concentration, the impact on firm performance. Asian Finance Association (AsianFA) Conference 2009 (pp. 1-51). Brisbane: University of Queensland Business School (UQBS)

56. Mahakud J, Misra AK (2009) Effect of leverage and adjustment costs on corporate performance. Journal of Management Research 9(1):35-42

57. Manna A, Sahu TN, Gupta A (2016) Impact of ownership structure and board composition on corporate performance in Indian companies. Indian Journal of Corporate Governance 9(1):44-66

58. Matusin AR, Andryan R, Pamela A (2014) The impact capital structure on agency cost of Indonesian listed companies. The 2nd IBEA - International Conference on Business, Economics and Accounting, Hong Kong

59. McConnell JJ, Servaes H (1990) Additional evidence on equity ownership and corporate value. J Financ Econ 27(2):595612

60. Miguel AD, Pindado J, Torre CDL (2004) Ownership structure and firm value: new evidence from Spain. Strateg Manag J 25:1199-2107

61. Mínguez-Vera A, Martín-Ugedo JF (2007) Does ownership structure affect value? A panel data analysis for the Spanish market. Int Rev Financial Anal 16(1):81-98

62. Mishra P (2008) Concentration-markup relationship in Indian manufacturing sector. Economic Political Weekly 43(39):7581

63. Mishra R, Kapil S (2017) Effect of ownership structure and board structure on firm value: evidence from India. Corporate Governance: The International Journal of Business in Society 17(4):700-726

64. Mittal SS, Anjala K (2018) The relationship between corporate governance, ownership concentration and firm performance: empirical evidence from India. IIMS Journal of Management Science 9(1):1-13

65. Morck R, Yeung B (2003) Agency problems in large family business groups. Entrepreneurship Theory Practice 27(4):367382

66. Niresh JA (2012) Trade-off between liquidity \& profitability: A study of selected manufacturing firms in Sri Lanka. Researchers World 3(4):34-40

67. Pandey KD, Sahu TN (2017) An empirical analysis on capital structure, ownership structure and firm performance: evidence from India. Indian Journal of Commerce Management Studies 8(2):63-72

68. Pandey KD, Sahu TN (2019) Concentrated promoters' ownership and firm value: re-examining the monitoring and expropriation hypothesis. Paradigm 23(1):70-82

69. Pandey KD, Sahu TN (2019b) Debt financing, agency cost and firm performance: evidence from India. Vision 23(3):267274

70. Pant M, Pattanayak M (2007) Insider ownership and firm value: evidence from Indian corporate sector. Economic Political Weekly 42(16):1459-1467

71. La Porta R, Lopez-de-Silanes F, Shleifer A (1999) Corporate ownership around the world. The Journal of Finance 54(2):471-517

72. Pound J (1988) Proxy contests and the efficiency of shareholder oversight. J Financ Econ 20:237-265

73. Roe MJ (2003) Political determinants of corporate governance: political context, corporate impact. Oxford University Press, New York

74. Roe MJ (2004) The institutions of corporate governance. Discussion Paper No. 488, Harvard Law School

75. Saleem Q, Rehman RU (2011) Impacts of liquidity ratios on profitability. Interdisciplinary Journal of Research in Business 1(7):95-98

76. Saravana P (2009) Corporate governance characteristics and company performance of family owned and non-family owned business in India. Great Lakes Herald 3(1):39-54 
77. Sargan JD (1958) The estimation of economic relationships using instrumental variables. Econometrica: Journal of the Econometric Society 26(3):393-415

78. Sahut JM, Gharbi HO (2010) Institutional investors' typology and firm performance: the case of French firms. Int J Bus 15(1):33-49

79. Selarka E (2005) Ownership concentration and firm value: a study from the Indian corporate sector. Emerging Markets Finance Trade 41(6):83-108

80. Shakir R (2008) Effect of block ownership on performance of Malaysian property companies. Pacific Rim Property Research Journal 14(4):361-382

81. Shleifer A, Vishny RW (1986) Large shareholders and corporate control. J Polit Econ 94(3):461-488

82. Shleifer A, Vishny RW (1997) A survey of corporate governance. The Journal of Finance 52(2):737-783

83. Striewe N, Rottke N, Zietz J (2013) The impact of institutional ownership on REIT performance. J Real Estate Portfolio Manag 19(1):17-30

84. Stulz R (1990) Managerial discretion and optimal financing policies. J Financ Econ 26(1):3-27

85. Tawiah VK, Benjamin M, Banns JE (2015) Nexus between ownership structures and shareholders' wealth. International Journal of Multidisciplinary Research Development 2(4):226-231

86. Ting HI (2013) The influence of insiders and institutional investors on firm performance. Review of Pacific Basin Financial Markets Policies 16(04):1350027

87. Tsai H, Gu Z (2007) Institutional ownership and firm performance: empirical evidence from US-based publicly traded restaurant firms. Journal of Hospitality Tourism Research 31(1):19-38

88. Vintila G, Gherghina SC, Nedelescu M (2014) The effects of ownership concentration and origin on listed firms' value: empirical evidence from Romania. Romanian Journal of Economic Forecasting 17(3):51-71

89. Welch E (2003) The relationship between ownership structure and performance in listed Australian companies. Aust $J$ Manage 28(3):287-305

90. Wintoki MB, Linck JS, Netter JM (2012) Endogeneity and the dynamics of internal corporate governance. J Financ Econ 105(3):581-606

91. Wooldridge JM (2009) Introductory econometrics: a modern approach, 4th Edition, South-Western Cengage Learning, Mason

92. Zeitun R (2009) Ownership structure, corporate performance and failure: evidence from panel data of emerging market the case of Jordan. Corporate Ownership Control 6(4):96-114

\section{Figures}

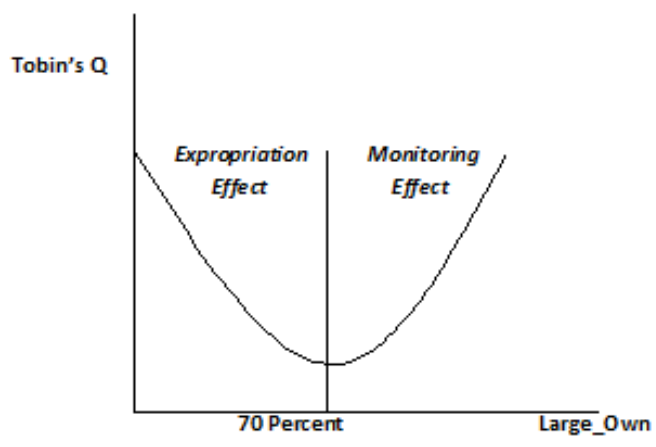

Figure 1

Page 20/21 
Threshold level of Large_Own

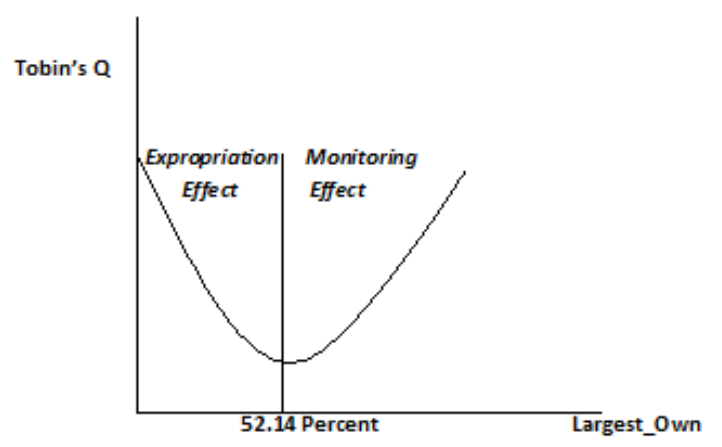

\section{Figure 2}

Threshold level of Largest_Own 